E3S Web of Conferences 1, 36001 (2013)

DOI: $10.1051 / \mathrm{e} 3$ sconf/20130136001

(C) Owned by the authors, published by EDP Sciences, 2013

\title{
The UNEP Global Mercury Assessment: Sources, Emissions and Transport
}

\author{
G. Futsaeter ${ }^{1}$ and S. Wilson ${ }^{2}$ \\ ${ }^{1}$ United Nations Environment Programme (UNEP) Chemicals Branch, DTIE, International Environment House , 11-13 \\ Chemin des Anémones, CH-1219 Châtelaine, Geneva, Switzerland, gunnar.futsaeter@unep.org \\ 2 Arctic Monitoring and Assessment Programme (AMAP) Secretariat, Gaustadalleen 21, N-0349 OSLO, Norway, \\ s.wilson@inter.nl.net
}

\begin{abstract}
Global Mercury Assessments (GMAs) have been produced as part of the UNEP Mercury Programme upon the request of UNEP Governing Council since 2001. The first GMA concluded that there is sufficient evidence of significant global adverse impacts from mercury and its compounds to warrant further international action to reduce the risks to human health and the environment from the release of mercury and its compounds to the environment. The follow-up "Global Atmospheric Mercury Assessment: Sources, Emissions and Transport" was delivered to the UNEP Governing Council in 2009. These reports formed the basis for the UNEP Governing Council policy decisions that have resulted in the ongoing (INC) process to establish a global legally binding instrument on mercury by 2013. UNEP is currently updating the 2008 "Global Atmospheric Mercury Assessment: Sources, Emissions and Transport," for presentation to the UNEP Governing Council in early 2013. The updated report will present a new inventory of anthropogenic atmospheric mercury emissions for all countries, based on best available data from 2008-2010, including an analysis by sector and region. This part of the report is being developed by a joint AMAP/UNEP expert group. The report will also present updated information on atmospheric transport and deposition and - as a new addition - information on aquatic releases of mercury and on mercury fate and transport in aquatic environments. These parts of the report will be delivered by the UNEP Partnership Area on Mercury Fate and Transport. An outline of the methodology used to develop the report, and preliminary scientific results will be presented.
\end{abstract}

Key words: mercury, global mercury emissions, UNEP

\section{Introduction}

Mercury At the UNEP Governing Council meeting in 2009, UNEP was requested "in consultation with Governments, to update the 2008 report entitled "Global Atmospheric Mercury Assessment: Sources, Emissions and Transport" for consideration by the Governing Council at its twenty-seventh session" in 2013.

At the UNEP Governing Council (GC) meeting in 2009 , the GC also decided to develop a global legallybinding instrument on mercury. The negotiation of the text of the instrument is to be completed in 2013 prior to the twenty-seventh regular session of the Governing Council.

Although the work to establish a global mercury agreement is clearly separated from the mandate to produce an updated global mercury assessment report, the updated assessment, including updated estimates of global mercury emissions as well as national emissions estimates, may be an important document in the interim period prior to entry into force of an eventual global agreement. It is therefore important that the report is widely accepted by governments.

\section{Methods and Materials}

The overall responsibility for implementing the project "Global emissions, transport and fate of mercury" resides with UNEP's Chemicals Branch, Division of Technology, Industry and Economics.

For the emissions components of the work, a core expert group have prepared preliminary emissions estimates based on available data sources for discussion with national experts. This work is being supported through a collaboration between UNEP and the Arctic Monitoring and Assessment Programme (AMAP). A 
major emphasis is placed on the active involvement of experts from all UN regions, and in particular from major emitting countries. The engagement of this extended network of experts is vital not only to ensure that up-todate national data are made available to the process but also to ensure that governments are fully consulted and are 'partners' in the development of the reports and share ownership of them. The aim has been to develop a comprehensive 2010 inventory as a basis for the assessment. However since data for this year has only become available late in the project, the inventory will utilize data for the period 2008-2010, with every effort being made to include the latest available data. Planned deliverables also include an updated spatially-distributed (gridded) 2010 global inventory of anthropogenic emissions to air for use in modelling work; and potentially updated scenario inventory datasets, and model results utilizing these data.

The work will emphasise anthropogenic emissions; however natural emissions and (re)emissions associated with environmental recycling of mercury released by natural and anthropogenic sources will be described.

The report will also address the transport and fate of atmospheric mercury and, as a new addition to the report information on aquatic mercury releases, transport and fate. These sections of the report will be prepared by the UNEP Partnership Area on Mercury Fate and Transport (F\&T).

Expert workshops have been arranged to engage international and regional experts in the work to prepare atmospheric emission estimates, and to coordinate the production of the updated report.

Preliminary emissions estimates, including data derived from national inventories of mercury releases that have been carried out in various countries in the recent years, will be circulated over the summer for national review.

The updated GMA report will be based on existing and ongoing studies including the UNEP Paragraph 29 study (Study on mercury sources and emissions, and analysis of cost and effectiveness of control measures)(UNEP, 2010); the most recent AMAP Assessment of Mercury in the Arctic (AMAP 2011); the report on mercury developed by the UNECE LRTAP Convention Task Force on Hemispheric Transport of Air Pollutants (HTAP) (HTAP 2010); the report on Mercury Releases to the Aquatic Environment developed by Joint
Group of Experts on the Scientific Aspects of Marine Environmental Protection (UNEP 2011); a report on Mercury Releases from Contaminated Sites (Horvat (Ed.), Jožef Stefan Institute, Slovenia, 2011); preliminary results from the EU-funded Global Mercury Observation System (GMOS) project, and results from national inventories developed by national officials using the UNEP Mercury Toolkit.

UNEP will work closely with its partners in the UNEP Partnership area for Mercury Air Transport and Fate Research to ensure close coordination and integration of the above mentioned work. Specifically the partnership will contribute with information on releases to the aquatic environment, and atmospheric and aquatic chemistry, transport and modelling.

The draft reports will be subject to an open review by governments, experts and stakeholders. The technical report will be peer reviewed by selected scientists.

\section{Acknowledgements}

UNEP acknowledge the work of the Arctic Monitoring and Assessment Program (AMAP), the financial support to the work from the Norway, Sweden, Denmark, and Nordic Council of Ministers provided directly to AMAP, the financial support to UNEP from Canada and the European Commission, and the work of the UNEP Partnership area on Mercury Fate ad Transport.

\section{References}

UNEP, 2008. The Global Atmospheric Mercury Assessment: Sources, Emissions and Transport, United Nations Environmental Programme, Chemicals Branch, DTIE, Geneva, Switzerland, December 2008.

UNEP, 2010. Study on mercury sources and emissions, and analysis of cost and effectiveness of control measures "UNEP Paragraph 29 study". United Nations Environmental Programme, Chemicals Branch, DTIE, Geneva, Switzerland, November 2010.

HTAP, 2010. Hemispheric transport of Air pollution 2010, UNECE Air Pollution Studies no. 18, Part B: Mercury.

AMAP, 2011. AMAP Assessment of Mercury in the Arctic. 